\title{
Comparative analysis of disaster risk management practices in Bucharest, Ciudad de Mexico and Istanbul
}

\author{
Ana-Maria GLOD-LENDVAI \\ University of Bucharest, Faculty of Geography, \\ ana-maria.lendvai@drd.unibuc.ro
}

\begin{abstract}
Natural disasters represent a major problem for many big cities. The biggest part of the population is in cities, which makes the concept of urban planning be a significant problem for the decision makers. In this paper, there are presented the results of a comparative analysis of the disaster risk management practices between Bucharest and Ciudad de Mexico in South America; and Istanbul in the euro-Mediterranean region. The analysis shows that all three cities have made considerable efforts regarding the risk analysis, especially in earthquakes. The elements they took into consideration are: the political engagement, identifying risks, the institutions and managing knowledge. Finally, the papers concludes by reasoning that the local authorities must focus more on reducing risks in order to reduce the physical vulnerability and to reach urban durability.
\end{abstract}

Keywords: disaster risk management, urban hazard risk, urban sustainability, geospatial information systems (GIS), earthquakes, vulnerability.

\section{Introduction}

Natural disasters were associated in the past with rural populations and poor countries (Mitchell, 1999a). But as the world's population continues to move to urban areas (Ghajari et al., 2017), cities are facing a high risk of natural and anthropic disasters (Sennewald, 2016).

Vulnerability in case of disasters is higher today than in the past as a result of population growth, the number and complexity of buildings, services and infrastructure in a city (Ilkisik et al., 2010). Thus, very large cities begin to be affected by disasters in ways that challenge available scientific knowledge and existing management institutions (Mitchell, 1999b). The economic and human losses caused by natural hazards are influenced by the quality of urban management and exacerbated by the lack of urban expansion planning (World Bank, 2011). Economic damages produced annually globally are of several billion dollars (Guha-Sapir and et al., 2011). This estimate takes into account the effects of physical damage on the built environment, the cost of care for the population and economic losses (Walker et al., 2014). Unless action is taken to identify and manage the risks of disasters, the resulting losses will have serious implications for the safety, quality of life and economic performance of cities (World Bank, 2011).

Identifying potential risks and developing urban vulnerability reduction plans are key to achieving urban sustainability (Li et al., 2016; Sharifi, 2016). Cities can better plan and respond if the location and nature of risk is known and also if risk assessment and management processes are integrated into urban management and development programs (World Bank, 2011).

Risk management must identify urban vulnerability and suggest measures to reduce it (Cardona, 2005). The vulnerability of the population to an earthquake or other disaster depends on the combination of factors that directly affect them (e.g. structural damage and access to trauma centres) and indirect (e.g. socio-economic disadvantage) (Rygel et al., 2006, Flanagan et al., Fekete 2012; Smith 2013, Ghajari et al., 2017). And, urban vulnerability is the degree of damage to a city's components (Brooks, 2003).

Risk management plans have four stages: risk reduction, training, response and recovery (World Bank, 2011). Risk management is an integral part of urban crisis management (Cervelli et al., 2016) and many studies have been undertaken on the application of GIS in crisis management and 
modelling under different risk conditions (Armaş and Radulian, 2014; Nejad et al., 2015; Zhao and Liu, 2016; Khamespanah et al., 2016). Thus, GIS-based decision analysis techniques have been used in disaster assessment, risk prioritisation and land use planning (Ghajari et al., 2017).

The present study builds on existing research demonstrating how natural hazards pose threats to the safety of the population. For example, earthquakes have been major natural hazards since the last century in major cities: Tokyo, Los Angeles,
San Francisco, Mexico City, Lima, Istanbul and Bucharest (Mitchell, 1999b; Mitchell, 1999c; Gheorghe and Armaş and Gheorghe, 2015).

This study aims to analyse disaster prevention / reduction plans in Bucharest and other two major cities: Istanbul and Ciudad de Mexico. We chose these two cities due to the presence of the metro line, the fact that they are cities with a high population and the high potential for a seismic occurrence (Fig. 1).

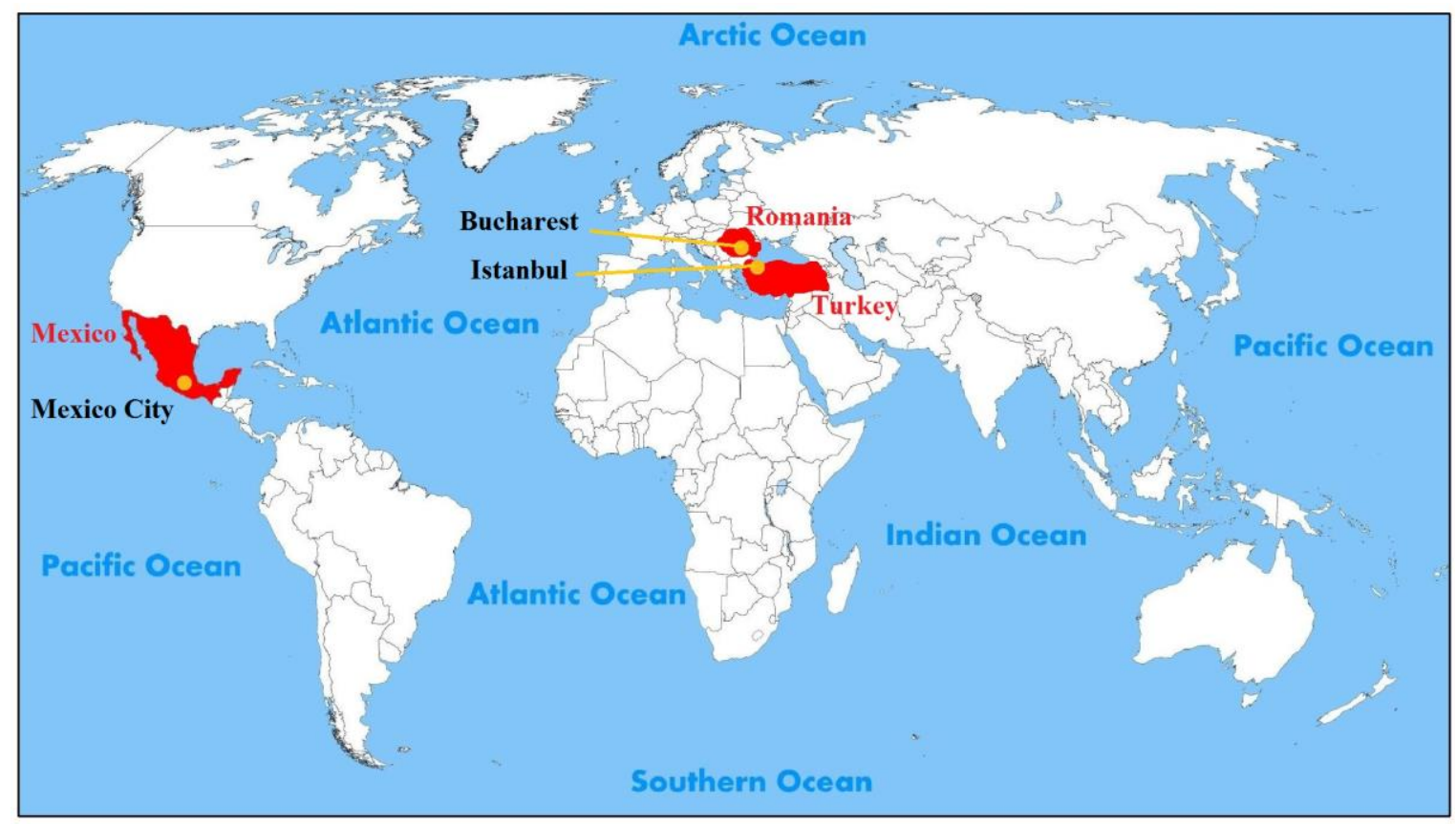

Figure 1. Location of the Bucharest, Mexico City and Istanbul cities

\section{Approaches to urban risk management and planning}

Urban risk assessment is ideally carried out as part of a cyclic risk assessment process, development and implementation of a risk management plan and monitoring of progress in risk reduction (World Bank, 2011). However, the most widespread form of public or private service is the planning of postdisaster reconstruction activities in urban areas (Spangle, 1991). Although the potential role of urban planning in reducing earthquake damage is often mentioned, the number of cases of plans or implementations in this area is very rare (Balamir, 2004).

The disaster preparation plan has the following elements: hazard identification; assessment of areas and critical activities (industries, infrastructure); loss estimation (economic modelling); establishing the optimal reduction strategy; risk reduction (microzonation, early warning); preparing the response team; communication and education (World Bank, 2018).

\subsection{Seismic risk management and planning in Istanbul city}

The city of Istanbul has been an important centre in the social, economic, geopolitical, commercial and cultural spheres for at least two millennia. Although Istanbul is a very old city, it grew very fast, especially after the 1950s. Thus, its population increased from 1 million (in the 1950s) to 12 million (Ilkisik et al., 2010). And, the number 
of buildings has reached about 1,300,000 (Nilay et al., 2019). Istanbul and its surroundings are the settlements that have been affected by many earthquakes throughout history. Historical records for the past 2000 years (Ambrayses, 2002) statistically reveal the re-emergence of a destructive earthquake that strikes Istanbul every century (Nilay and colab., 2019). The last two major seismic events that took place in eastern Marmara in 1999 are the earthquakes from Kocaeli and Dâmbătă. Although Istanbul is $90 \mathrm{~km}$ from the epicenter of these earthquakes, the damage to many buildings and the loss of life were great (Ersoy and Koçak, 2015).

Istanbul's problems with seismic risk range from the poor technical quality of buildings to uncontrolled urban growth and an inflexible planning system that remains incompatible with city dynamics (Ilkisik et al., 2010). The JICA study (2002) estimated that a major earthquake of $\mathrm{Mw}=$ 7.4 near Istanbul could cost more than 50,000 lives and cause economic losses of more than 60-70 billion dollars. A study performed by the Construction Chamber (2005), which is based on 1278 buildings $(0.1 \%$ of the total) in different locations in Istanbul, indicates a medium quality of concrete (Nilay and colab., 2019). The high seismic potential of North-Anatolian Plates (NAF) in the Sea of Marmara poses a great risk to Istanbul (Ersoy and Koçak, 2015). Also the construction of the metro tunnels between Taksim and Yenikapi caused damage to a building in the French consulate (Seeley, 2001).

In view of these risks, the Istanbul Metropolitan Municipality runs a micro-zoning project in the south-western part of the city and has recently set up the Disaster Coordination Centre (AKOM) to improve preparation and seek reduction and prevention options (Fernandez et al., 2019; Nilay et al., 2019). Studies on "Istanbul's earthquake risk assessment" and finding suitable solutions for complex "risk reduction" issues, "Istanbul's General Earthquake Plan (EMPI)" was commissioned by the Istanbul metropolitan municipality (IMM) to a consortium that involves four universities in Turkey. The EMPI was completed in 2003 and identified 13 risk sectors. Implementation of the EMPI was done in the Zeytinburnu district, which was determined in the JICA and EMPI study as one of the risky neighbourhoods in Istanbul (Ilkisik et al., 2010).

The scope of the Earthquake Master Plan for Istanbul includes work to be done in the following areas: assessment of the current situation; seismic assessment and rehabilitation of existing buildings; aspects of urban planning; legal issues; financial issues; educational issues; social issues; issues of risk management and disasters. The Istanbul Metropolitan Municipality has also set up a strategic plan for Istanbul's disaster mitigation (SPDMI) to reduce seismic risk by focusing on the construction of buildings resistant to disaster (World Bank, 2018).

\subsection{Seismic risk management and planning in Ciudad de Mexico city}

The city of Mexico is one of the largest urban agglomerations in the world. This city has grown steadily since the 1930s both physically and demographically, reaching the climax in the 1960s, and by the 1990s physical expansion (urban expansion) has formed a continuous urbanized area (World Bank, 2011). Mexico City has the largest metro system in Latin America, over $200 \mathrm{~km}$ (Dickson et al., 2012). The city of Mexico extends in all directions, but mainly to the east and north, where there are less restrictive physical barriers. On the one hand, much of the older, but not necessarily poorer, central city is exposed to high earthquake risks, while most peripheral areas are relatively safe in earthquakes (Mitchell, 1999a).

The geophysical characteristics of the city, the size of the population and the presence of the risk of multiple natural hazards underline the city's need to implement urban management programs (World Bank, 2011). The last major earthquake in Mexico was in 1985 and was 8.2M magnitude (Nadelman et al., 2019).

The international community has drawn attention to the disaster risk of Mexico City. The World Bank is involved in disaster risk assessment in Mexico, making recommendations to reduce this risk and support the process. The World Bank recommends Mexico to adopt a three-steps approach: to identify risks, reduce possible damage 
and transfer risk to insurance companies and capital markets (Kreimer et al., 1999).

The Mexican Government is duly focusing on four key areas: "Strengthening the regulatory and supervisory requirements of the insurance sector, establishing a comprehensive disaster financing structure, promoting public insurance policies related to loss reduction programs in uninsured sectors, and strengthening risk assessment and the implementation of structural measures, such as micro-zoning and building code compliance". (Guerra-Fletes, et al, 2006).

The Urban Risk Assessment Approach (URA) can be initiated as part of the urban planning process so that it can be integrated with existing urban management tools and functions (World Bank, 2011).

The URA methodology has been implemented in four cities (Mexico City, Jakarta, Dar es Salaam and São Paulo) and will be done again with the support and guidance of various international agencies as it is launched globally.

In the two decades since the earthquake, Mexico has taken important steps in addressing the risks of earthquakes and other dangers. These are: technological advances in earthquake monitoring and citizen training programs (evacuation simulations, disaster readiness in hospitals). This includes developing their geographic information systems (GIS) capabilities and modelling for risk assessment and anticipation. The Community was actively involved in the 1985 recovery process, which led to the creation of the Ministry of Social Development in 1987 (Secretaria de Desarrollo Social - SEDESOL) with a role in improving communication and cooperation between the government and civil society (Nadelman et al., 2019).

For monitoring and warning in the event of earthquake, it was implemented in Mexico in 1991 The seismic alert system (SAS) (Cuauhtémoc et al., 2005). The most important of these include: The National Civil Protection System (Sinaproc) set up in 1987 to coordinate disaster readiness and response and the 1988 National Centre for Disaster Prevention (CENAPRED) hosted by the Autonomous National University of Mexico to link the world research and policy (Kreimer et al., 1999).
In 1996, the Mexican government created the Fund for Natural Disasters (Fundo para Desastres Naturales (FONDEN), made up of three separate funds for infrastructure, agriculture and individual assistance (Earthquake Engineering Research Institute (EERI), 2003).

In order to increase FONDEN's ability to fulfil these responsibilities, in 2002 the World Bank provided FONDEN with funds of 404 million USD, allocated for re-capitalisation and disaster management activities (UN/ISDR, 2004,).

Since January 2015, the early warning system of the meteorological phenomenon has been functioning. It was produced by the Mexican Spanish Meteorological Service (SCiESMEX). The aim is to provide a verified warning to the Mexican Centre for Disaster Prevention (CENAPRED) and to the public almost in real time (De la Luz et al., 2017).

\subsection{Seismic risk management and planning in Bucharest city}

The city of Bucharest covers an urban area of about $285 \mathrm{~km}^{2}$ and is located in the impact area of the Vrancea earthquakes (Fig. 2). In the case of Bucharest, the geometry of the source of Vrancea earthquakes with intermediate depth remains almost the same throughout the city (Bala et al., 2011). The earthquake that occurred on March 4, 1977, caused the collapse of 32 high-rise buildings in the central area of Bucharest and the deterioration of many buildings (Mândrescu et al., 2007).

Bucharest is a city with over two million inhabitants and rapidly developing. Thus, the civil engineering industry is facing new challenges related to the need to have deeper buildings with deeper underground, a developing network of subway lines and several bridges with foundations made of large diameter stones. All of these new works have an important impact on the stability of the upper soil (Poncos et al., 2013).

Because post-disaster planning is essential for providing emergency services and other civil protection services in affected areas (Merciu et al., 2018) the risk analysis and coverage plan was adopted (PAAR). 


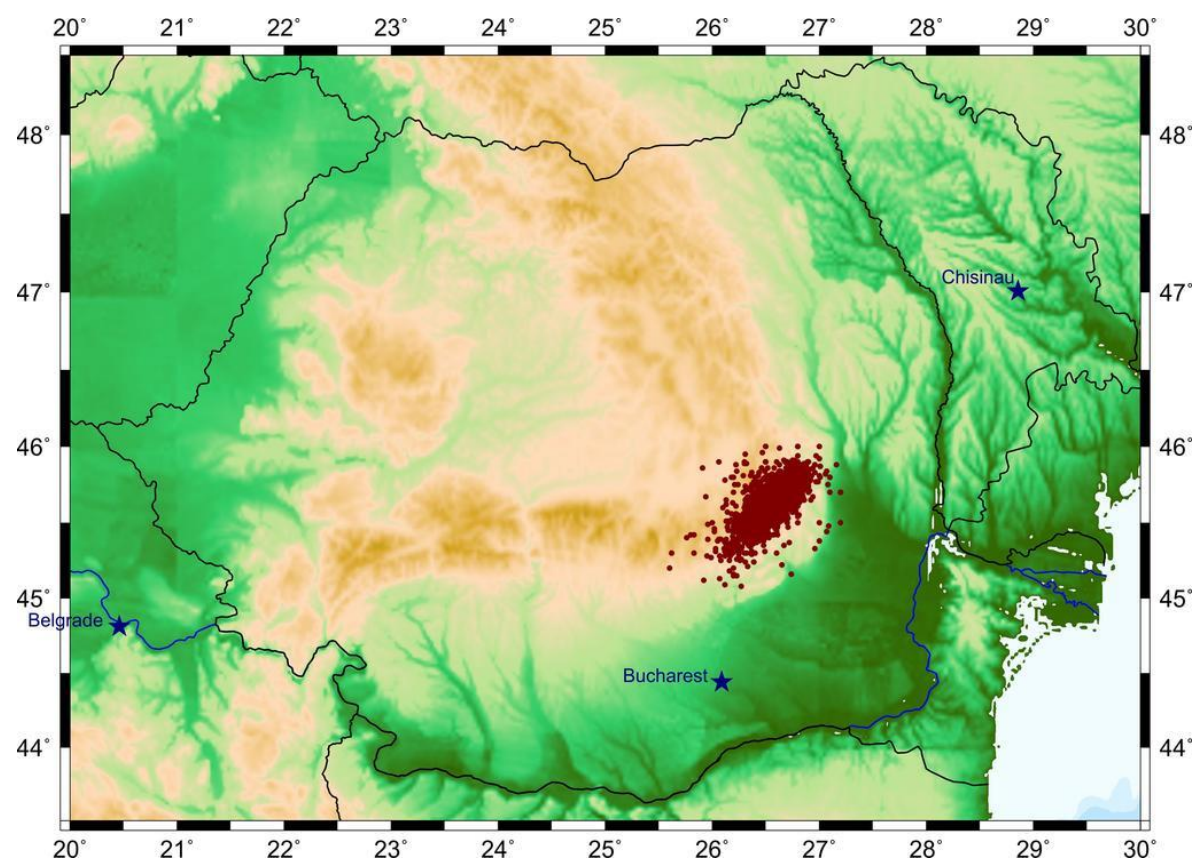

Figure 2. Subcrustal seismicity of the Vrancean epicenter (depth>60 km) (ROMPLUS catalogue,

Oncescu and colab., 1999)

PAAR includes: the potential risks identified at the level of the administrative-territorial units, the measures, the actions and the resources necessary for the risk management.

PAAR's objectives are to ensure that all factors involved know the tasks and attributions that occur prior to, during and after the emergence of an emergency situation, to create a united and coherent framework of action for the prevention and management of emergency generating risks and to ensure an optimal response in an emergency, appropriate to each identified risk type.

The design of the capacities and resources necessary for the response, their planning so as to minimize the human and material losses, cannot be achieved without an assessment as close as possible to the reality of the seismic hazard present in the capital. In the case of a high intensity earthquake, it is necessary to analyse the emergency situations that can be generated by the damage of the high and very high buildings in Bucharest and the way of intervention in these buildings. The area with the highest seismic risk at the city level is the historical centre (Gheorghe and Armaş, 2015).

Also in 2016 a rescue command point (fire brigade, doctors, and representatives of public utility companies) was put into use in Bucharest and will bring together the dispatchers of all forces intervening in the event of a major disaster (Ichim, spokesman for Bucharest Town Hall).

\section{Comparative analysis}

Vulnerability is the potential for loss. The most common change in the components of the hazard is the increase in polarization and spatial segregation of groups with different degrees of vulnerability to disaster. Qualitative contrasts are the clearest in major cities in developing countries (e.g. Mexico City, Lima, Dhaka, Bucharest), "but the sheer volume of recently arrived poor migrants from rural areas tips the quantitative effect heavily towards the poor end of this spectrum" (Mitchell, 1999a).

Recently, several organizations and researchers have focused their interest in developing standardized tools to help governments and stakeholders understand, monitor and establish disaster risk indicators and benchmarks, among which Cardona (2010), Mitchell (2003) and other organizations such as PNUD and the World Bank. The World Disaster Reduction Conference, organized in January 2005 in Kobe, Hyogo-Japan, adopted a "Framework for Action 2005-2015: Strengthening the Resilience of Nations and 
Communities in case of Disaster", known as the Hyogo Framework for Action - HFA. This framework includes five thematic areas that set out an initial core of principles and objectives, each of which includes several key components to be analysed (Fernandez et al., 2019): political commitment and institutional development (governance); identifying risks; knowledge management; applications for risk management; preparation and management of emergency situations.

Istanbul is definitely ahead of the overall management plans in the catastrophic risk implementation process. The practice, which reflects the efforts of the city to reduce physical, social and institutional vulnerability, Istanbul City Hall (IMM) has requested at four major technical universities: Bogazici, Istanbul, Middle East and Yildiz, to prepare a Master Plan for Earthquake in Istanbul. For the implementation process, the city decided to focus on urban renewal, refurbishment of selected structures, application of building codes and universal earthquake insurance for general purpose buildings (Fernandez et al., 2019).

In 2015, the PEER report (Evaluation Program for EU cooperation) was presented. This report is an analysis of the situation in Turkey as presented in December 2015. Turkey's risk management system is organized around the risk management cycle and is particularly strong in terms of readiness and response (EERP). The problematic areas in the Turkish legal system that may create obstacles to these strategic plans are: issues related to institutional responsibilities; planning issues; issues related to the embedded environment (Fernandez et al., 2019)
Ciudad de Mexico introduced a system of disaster management indicators. This is a multidisciplinary system that takes into account the expected physical damage, the number and type of economic losses, as well as social, organizational and institutional factors such as social fragility and the lack of resistance of the exposed community. Scenarios of deterioration previously developed for the city are used together with a set of indicators to develop this urban management program. Thus, an earthquake (7.6 on the Richter scale) in the Southwestern state of Colima on January 21, 2003 tested the measures implemented by Mexico to improve disaster availability. A reconnaissance team at the Earthquake Engineering Research Institute (EERI) visited the municipalities of Colima, Manzanillo, Tecomán, Comala, Coquimatlán, Villa de Álvarez, Ixtlahuacan and Armería the day after the earthquake, investigating the effects of the earthquake as well as the government's response. The team described the response as "fast and well managed" (Reporting of damaged structures was mostly by public teams doing rapid visual assessments, Earthquake Engineering Research Institute, 2003),

The disaster risk in the city of Bucharest is treated in a reactive manner and limited preventive measures have been implemented. In addition, there is an obvious need to improve the exchange of information between relevant government agencies. However, implementation of the early warning Rapid Earthquake Warning System (REWS) is operational from 2013 (Ionescu et al., 2016).

Table 1. Comparative analysis of risk management and planning in Istanbul, Mexico City and Bucharest

\begin{tabular}{|l|l|l|l|}
\hline $\begin{array}{c}\text { Thematic } \\
\text { areas/ } \\
\text { Components }\end{array}$ & \multicolumn{1}{|c|}{ Istanbul } & \multicolumn{1}{c|}{ Mexico City } & \multicolumn{1}{c|}{ Bucharest } \\
\hline $\begin{array}{l}\text { Politics and } \\
\text { planning }\end{array}$ & EMPI & CENAPRED & PAAR \\
\hline Legislation & $\begin{array}{l}\text { Disaster Law } \\
\text { Civil Defence Law } \\
\text { Development Law } \\
\text { Law of Municipality }\end{array}$ & $\begin{array}{l}\text { General Civil Protection Law } \\
\text { (LGPC) } \\
\text { General Climate Change Law } \\
\text { (LGCC) }\end{array}$ & $\begin{array}{l}\text { Regulation on defence against the } \\
\text { effects of disasters caused by } \\
\text { earthquakes and / or landslides; } \\
\text { Regulation on Prevention and }\end{array}$ \\
\hline
\end{tabular}




\begin{tabular}{|c|c|c|c|}
\hline $\begin{array}{l}\text { Thematic } \\
\text { areas/ } \\
\text { Components }\end{array}$ & Istanbul & Mexico City & Bucharest \\
\hline & $\begin{array}{l}\text { (1958) } \\
\text { Building supervision } \\
\text { Law }\end{array}$ & $\begin{array}{l}\text { International Development } \\
\text { Cooperation Law (LCID) } \\
\text { Organic Law of the Army and } \\
\text { Air Force }\end{array}$ & $\begin{array}{l}\text { Management of Emergency } \\
\text { Situations specific to earthquake } \\
\text { risk and / or landslide; }\end{array}$ \\
\hline Resources & $\begin{array}{l}\text { National Allocation } \\
\text { Fund } \\
\text { Insurance for protection } \\
\text { against earthquakes, for } \\
\text { risk transfer adopted at } \\
\text { the level of nations }\end{array}$ & FONDEN & $\begin{array}{l}\text { Civil compulsory insurance in } \\
\text { case of earthquake } \\
\text { Building consolidation program of } \\
\text { Class I buildings of seismic risk } \\
\text { and posing public danger }\end{array}$ \\
\hline $\begin{array}{l}\text { Organizational } \\
\text { Structures }\end{array}$ & $\begin{array}{l}\text { Council of Disaster } \\
\text { Management Centre } \\
\text { (AYM) } \\
\text { Disaster Coordination } \\
\text { Centre (AKOM) }\end{array}$ & SEDESOL & $\begin{array}{l}\text { Emergency Situation Committee } \\
\text { of Bucharest Municipality, } \\
\text { Operational Centre with } \\
\text { Permanent Activity - ISUBIF } \\
\text { Local Committees for Emergency } \\
\text { Situations of Districts 1-6, } \\
\text { Operational Centre for Temporary } \\
\text { Activity }\end{array}$ \\
\hline $\begin{array}{l}\text { Risk } \\
\text { Assessment }\end{array}$ & $\begin{array}{l}\text { - Maps of seismic } \\
\text { activity } \\
\text {-Scenarios of } \\
\text { damages in case of } \\
\text { earthquakes } \\
\end{array}$ & $\begin{array}{l}\text { GIS maps for modelling, } \\
\text { assessing and anticipating risk }\end{array}$ & $\begin{array}{l}\text { - Maps of seismic activity } \\
\text {-Earthquake damage scenarios } \\
\text {-Death toll and fire damage } \\
\text { estimates available. }\end{array}$ \\
\hline Early Warning & $\begin{array}{l}\text { - Early warning system } \\
\text { that also aims at } \\
\text { preventing secondary } \\
\text { effects such as fire, gas } \\
\text { and electricity cuts. }\end{array}$ & Seismic alert system (SAS) & $\begin{array}{l}\text { Rapid Earthquake Early Warning } \\
\text { (REWS) }\end{array}$ \\
\hline $\begin{array}{l}\text { Education and } \\
\text { Training }\end{array}$ & $\begin{array}{l}\text { General aspects related } \\
\text { to Earthquake risks is } \\
\text { offered in primary and } \\
\text { high schools }\end{array}$ & $\begin{array}{l}\text { Evacuation simulations, } \\
\text { disaster readiness in hospitals }\end{array}$ & $\begin{array}{l}\text {-Little training or formal education } \\
\text { in primary and high schools }\end{array}$ \\
\hline Research & $\begin{array}{l}\text { Major focus has been } \\
\text { the physical } \\
\text { vulnerability of } \\
\text { buildings }\end{array}$ & $\begin{array}{l}\text { Technical studies related to } \\
\text { risk monitoring }\end{array}$ & $\begin{array}{l}\text {-Mainly technical research } \\
\text { addressed to construction, } \\
\text { hazards monitoring, }\end{array}$ \\
\hline
\end{tabular}

\section{Conclusions}

For risk management to be effective, it can no longer be a separate aspect of urban management; it must become a component of integrated programs that are designed to respond to the wider objectives of urban sustainability. Consequently, the purpose of risk management projects is to bring together and activate in every sector of risk, the related components of public administration, business and industry, NGOs and representatives of local communities in the long-term management of urban risks, to conclude mutual understanding of conduct and control (Nilay et al., 2019).
This study evaluated the suggestions for risk management projects in Bucharest, Ciudad de Mexico and Istanbul. Following the analysis of these projects, we can say that the most complete risk management project is in Istanbul. Project, which can be taken as example to improve the risk management situation for Bucharest.

Risk analysis and assessment, especially earthquake risk, does not seem to be a problem in the studied cities. All these cities have a good understanding of the dangers they face and major social and structural vulnerabilities have been identified; Consequently, the associated risks are fairly well known and accurately mapped. However, 
serious limitations on governance and knowledge management have occurred in most cities.

\section{REFERENCES}

Ambraseys NN. 2002. Seismic sea-waves in the Marmara sea region during the last 20 centuries. J Seismol. 6:571_578.

Armas, I.; Radulian, M. Spatial multi-criteria risk assessment of earthquakes from Bucharest, Romania. In Earthquake Hazard Impact and Urban Planning; Springer: New York, NY, USA, 2014; pp. 127-149.

Bala, Andrei şi Hannich, Dieter şi R. R. Ritter, J \& Ciugudean-Toma, V. (2011). Geological and geophysical model of the quaternary layers based on in situ measurements in Bucharest, Romania. Romanian Reports in Physics. 63. 250-274.

Balamir, Murat. (2019). Urban seismic risk management: the earthquake master plan of Istanbul (EMPI) Approaches to Urban Risk Management and Planning.

Brooks, N. Vulnerability, Risk and Adaptation: A Conceptual Framework; Tyndall Centre for Climate Change Research: Norwich, UK, 2003; Volume 38, pp. $1-16$.

Cardona, O.D. 2010, “Application and Robustness of the Holistic Approach for Disaster Risk Assessment of Urban Centers." Presentation to the World Bank, June 2010.

Cardona, Omar D. "Indicadores de riesgo de desastre y de gestión de riesgos. Programa para América Latina y el Caribe; informe re- sumido". Banco Interamericano de Desarrollo-Departamento de Desarrollo Sostenible-División de Medio Ambiente, 2005 [en lí- nea]. [Fecha de consulta: octubre de 2015.] Disponible en: http:// www.cepal.org/ilpes/noticias/paginas/0/35060/Indicat ores de Riesgo de dezastres bid.pdf "La gestión del riesgo colectivo. Un marco conceptual que encuentra sustento en una ciudad laboratorio" [en línea]. [Fecha de con- sulta: octubre de 2015.] Disponible en: http://www.desenredando. org/public/articulos/2007/articulos_omar/Gestion_Rie sgo_Ciudad_Laboratorio21-09-05LaRED.pdf

Centro Nacional de Prevención de Desastres (Cenapred, 2001), Diagnóstico de peligros e identificación de riesgos de desastres en México. Atlas nacional de riesgo de la República Mexicana, México.

Cervelli, E.; Micheletti, S.; Rigillo, M. Proactive Risk Management and Integrated Knowledge for the Governance of Urban Systems: Urban Vulnerability in the Case of Gran Santo Domingo. Procedia Soc. Behav. Sci. 2016, 223, 750-757.

Comitetul Municipiului Bucureşti pentru situaţii de urgenţă, Planul de analiză şi acoperire a riscurilor Municipiului Bucureşti

(PAAR), http://isubif.ro/local/planul-de-acoperire-si-analiza-ariscurilor-bucuresti/

Cuauhtémoc, Abarca Chávez, Manuel Aguilera Gómez, Antonio Azuela de la Cueva, Manuel Camacho Solís,
Priscilla Connolly, René Coulomb, Roberto EibenschutzH., Alberto Franco Sarmiento, Mario Garza Salinas, Juan Ricardo Gil Elizondo, Enrique González Torres, Javier Hidalgo, Roberto Medi, Pedro Moctezuma Barragán, Raúl Monge, Alejandra Moreno Toscano, Sergio Puente Aguilar, Roberto Quaas Weppen, Marco Rascón, Daniel Rodríguez Velázquez, Alejandro Suárez Pareyón, Javier Urbina Soria, Alejandro Varas Orozco, Arturo Vilchis Esquivel, Luuis Wintergert Toledo, Alicia Ziccardi, (2005) '20 Años Después: Los Sismos de 1985', UNAM, Coordinadora de Humanidades, PUEC, México

De la Luz, Victor and Gonzalez-Esparza, A \& Sergeeva, Maria and Corona-Romero, Pedro and Mejia-Ambriz, Julio and X. González, L. (2017). The Mexican Early Warning System for Space Weather. Proceedings of the International Astronomical Union. 13. 236-239. 10.1017/S1743921317010158.

Dickson, Eric; Baker, Judy L.; Hoornweg, Daniel; Tiwari, Asmita. 2012. Urban risk assessments : understanding disaster and climate risk in cities (English). Urban development series. Washington, DC: World Bank. http://documents.worldbank.org/curated/en/65916146 8182066104/Urban-risk-assessments-understandingdisaster-and-climate-risk-in-cities

Earthquake Engineering Research Institute (EERI) (2003), 'Learning from Earthquakes Preliminary Observations on the Tecomán, Colima, Mexico, Earthquake of January 21, 2003', EERI Special Earthquake Report, March 2003, Earthquake Engineering Research Institute

Ersoy, Şükrü \& Kocak, Ali. (2015). Disasters and earthquake preparedness of children and schools in Istanbul, Turkey. Geomatics, Natural Hazards and Risk. 7. 1307-1336.

Fernandez, Jeannette \& Bendimerad, Fouad \& Mattingly, Shirley \& Buika, Jim. (2019). Comparative analysis of disaster risk management practices in seven megacities.

Flanagan BE, Gregory EW, Hallisey EJ, Heitgard JL, Lewis B (2011) A social vulnerability index for disaster management. J Homel Secur Emerg Manag 8:1547-7355

Fekete A (2012) Spatial disaster vulnerability and risk assessments: challenges in their quality and acceptance. Nat Hazards 61:1161-1178

Ghajari, Ebrahimian Yasser \& Alesheikh, Ali \& Modiri, Mahdi \& Hosnavi, Reza \& Abbasi, Morteza. (2017). Spatial Modelling of Urban Physical Vulnerability to Explosion Hazards Using GIS and Fuzzy MCDA. Sustainability. 9. 1274. 10.3390/su9071274.

Gheorghe Diana, Iuliana Armaş, GIS based decision support system support system for seismic risk in Bucharest. Case study- the historical centre, Journal of Engineering Studies and Research - Volume 21 (2015) No. 3, pag. 35-42

Guerra-Fletes, Francisco Fernandez and William Allison (2006) 'Mexico Disaster Recovery,' Financial Times, February 23 
Guha-Sapir D, Vos F, Below R, Ponserre S (2011) Annual disaster statistical review 2010: The numbers and trends. Cen Res Epidemiol Disasters. Universite catholique de Louvain, Brussels.

Ichim Alex, purtator de cuvant Primaria Bucuresti, 2016, Bucurestiul se pregateste pentru dezastru: Centru de comanda de 30 de milioane de euro, Sursa: Ziare.ro, http://www.ziare.com/social/primaria/bucurestiul-sepregateste-pentru-dezastru-centru-de-comanda-de-30de-milioane-de-euro-1408592

Ilkisik, O. M., Ergenc, M. N. and Turk, M. T. (2010) Istanbul Earthquake Risk and Mitigation Studies, Disaster Coordination Center, Turkey: pp. 1-8.

Ionescu, Constantin and Mărmureanu, Alexandru and Mărmureanu, Gheorghe. (2016). Rapid Earthquake Early Warning (REWS) in Romania: Application in Real Time for Governmental Authority and Critical Infrastructures. 10.1007/978-3-319-29844-3_31.

Khamespanah, F.; Delavar, M.R.; Moradi, M.; Sheikhian, H. A GIS-based multi-criteria evaluation framework for uncertainty reduction in earthquake disaster management using granular computing. Geod. Cartogr. 2016, 42, 58-68.

Kreimer, A. and Echeverria, Edward and (n.d), 'Case Study: Housing Reconstruction in Mexico City' World

Bank http://web.worldbank.org/wbsite/external/topics/xturu rbandevelopment/extdismgmt/0, contentmdk:20296276 isCURL:Y menuPK:124206 8 pagePK:148956 piPK:216618 theSitePK:341015, 00.html

Li, Y.; Zhang, X.; Zhao, X.; Ma, S.; Cao, H.; Cao,J. Assessing spatial vulnerability from rapid urbanization to inform coastal urban regional planning. Ocean Coast. Manag. 2016, 123, 53-65.

Mândrescu, Neculai \& Radulian, Mircea \& Mărmureanu, Gheorghe. (2007). Geological, geophysical and seismological data for site effects evaluation in the Bucharest urban area. 51. 43-70.

Merciu, Cristina \& Ianos, Ioan \& Merciu, GeorgeLaurențiu \& Jones, Roy \& G, Pomeroy. (2018). Mapping Accessibility for Earthquake Hazard Response in the Historic Urban Center of Bucharest. Natural Hazards and Earth System Sciences Discussions. 1-27. 10.5194/nhess-2018-41.

Metropolitan Municipality of Istanbul Planning and Construction Directoriat Geotechnical and Earthquake Investigation Department. Earthquake Masterplan for Istanbul. 2003. http://www.ibb.gov.tr/en-

US/SubSites/IstanbulEarthquake/Pages/IstanbulEarth quakeMasterPlan.aspx

Mexico's National Center for Disaster Prevention (CENAPRED)

http://www.proteccioncivil.gob.mx/Portal/PtMain.ph p?nIdHeader $=2 \&$ nIdPanel $=5 \&$ nIdFooter $=22$

Mexico Country Case Study Report - How Law and Regulation Supports Disaster Risk Reduction, UNDP, January 2014, https://www.undp.org/content/dam/undp/library/crisis\%2 0prevention/disaster/MEXICO\%20COUNTRY\%20C ASE\%20STUDY\%20REPORT\%20How\%20Law\%2 0and\%20Regulation\%20Supports\%20DRR.pdf

Mitchell, James. (1999a). Megacities and natural disasters: A comparative analysis. GeoJournal. 49. 137-142. 10.1023/A:1007024703844.

Mitchell J. K., 1999b: The re-emergence of environmental hazard as an urban problem, La Protezione Civile verso gli Anni 2000, Proceedings on the Conference on 'The Challenge of Major Hazards in Urban Areas on the Threshold of the New Millennium', Florence, Italy, 3-8 November 1998. CISPRO, Florence, pp. 127-135.

Mitchell J. K. (Ed.) 1999c: Crucibles of Hazard: Megacities and disasters in transition. United Nations University Press, Tokyo.

Mitchell T., (2003), An Operational Framework for Mainstreaming Disaster Risk Reduction, Benfield Hazard Research Centre, Disaster Studies, Working Paper 8, November 2003

Nadelman, Rachel \& Nichols, Caroline \& Rowbottom, Sara \& Cooper, Sarah. (2019). Learning from the Mexico City Earthquake: Dynamics of Vulnerability and Preparedness The Case of Housing.

Nejad, A.R.V.; Esmaeili, S.; Aghamohammadi, H. Earthquake risk modeling using GIS for urban buildings, case study: Tehran municipality, district 3 . Adv. Nat. Appl. Sci. 2015, 9, 36-43.

Nilay, M şi Ergenç, N şi Ilkışık, Osman şi T Turk, Murat. (2019). Earthquake risk and mitigation studies in Istanbul.

Oncescu M. C., Mârza V. I., Rizescu M. and Popa M. 1999. The Romanian earthquake catalogue between 984 -1996. In Vrancea Earthquakes: Tectonics, Hazard and Risk Mitigation (eds. Wenzel, F., Lungu, D., and Novak, O.) (Kluwer Academic Publishers 1999), pp. 43-49.

PEER Review Turkey 2015 2015-2016 Programme for peer reviews in the framework of EU cooperation on civil protection and disaster risk management, https://ec.europa.eu/echo/sites/echosite/files/turkey_peer_review_report___en.pdf

Poncos, Valentin şi Teleaga, D \& Patrascu, Carmen \& Datcu, Mihai. (2013). Monitoring Urban Subsidence in Bucharest City with TerraSAR-X.

Rygel L, O'Sullivan D, Yarnal B (2006) A method for constructing a social vulnerability index: an application to hurricane storm surges in a developed country. Mitig Adapt Strateg Glob Change 11:741764

Reporting of damaged structures was mostly by public teams doing rapid visual assessments, Earthquake Engineering Research Institute, 2003

Seeley Derek, 21-24 May 2001, Report on mission to report on the impact of subway construction on the World Heritage values of the historic areas of Istanbul (Turkey), Museum of London Archaeology Service (UK) 
Sennewald, C.A.; Baillie, C. Crisis Management. In Effective Security Management, 6th ed.; ButterworthHeinemann: Oxford, UK, 2016; Volume 19, pp. 189195.

Sharifi, A. A critical review of selected tools for assessing community resilience. Ecol. Indic. 2016, $69,629-647$.

Smith K (2013) Environmental hazards: assessing risk and reducing disaster. Routledge, NY Spangle, 1991

United Nations International Strategy for Disaster Reduction (UN/ISDR) (2004) Living with Risk: A Global Review of Disaster Reduction Initiatives, UN International Strategy for Disaster

Walker Blake Byron, Cameron Taylor-Noonan, Alan Tabbernor, T'Brenn McKinnon,Harsimran Bal, Dan Bradley, Nadine Schuurman, John J. Clague, A multi- criteria evaluation model of earthquake vulnerability in Victoria, British Columbia, Natural Hazards, 2014, Volume 74, Number 2, Page 1209

World Bank (2011). Urban risk assessments an approach for understanding disaster and climate risk in cities, http://www.worldbank.org/en/topic/urbandevelopmen t/publication/urban-risk-assessments

World Bank (2018). Istanbul Seismic Risk Mitigation and Emergency Preparedness Project TURKEY http://documents.worldbank.org/curated/en/41555146 8121763183/Turkey-Istanbul-Seismic-RiskMitigation-and-Emergency-Preparedness-Project

Zhao, M.; Liu, X. Reprint of: Regional risk assessment for urban major hazards based on GIS geoprocessing to improve public safety. Saf. Sci. 2016, 87, 18-24. 